\title{
Key Aspects on the Biology, Ecology and Impacts of Johnsongrass [Sorghum halepense (L.) Pers] and the Role of Glyphosate and Non-Chemical Alternative Practices for the Management of This Weed in Europe
}

\author{
Ilias S. Travlos 1,*(D), Jose M. Montull ${ }^{2}\left(\mathbb{D}\right.$, Gabor Kukorelli ${ }^{3}$, Goran Malidza ${ }^{4}$, \\ Mehmet N. Dogan ${ }^{5}$, Nikolina Cheimona ${ }^{1}$, Nikolaos Antonopoulos ${ }^{1}$, Panagiotis J. Kanatas ${ }^{6}$, \\ Stavros Zannopoulos ${ }^{7}$ and Gerasimos Peteinatos ${ }^{8}$ \\ 1 Agricultural University of Athens, 75, Iera Odos str., GR11855 Athens, Greece; \\ nikolinaxm@gmail.com (N.C.); nikolasantwno@gmail.com (N.A.) \\ 2 University of Lleida, 191, Av. de l'Alcalde Rovira Roure, E25198 Lleida, Spain; josemaria.montull@udl.cat \\ 3 Faculty of Agricultural and Food Sciences, Szechenyi Istvan University, H-9026 Gyor, Hungary; \\ kukorelli.gabor@gmail.com \\ 4 Institute of Field and Vegetable crops, Maksima Gorkog 30, 21000 Novi Sad, Serbia; \\ goran.malidza@ifvens.ns.ac.rs \\ 5 Faculty of Agriculture, Adnan Menderes University, Aydin 09100, Turkey; mndogan@adu.edu.tr \\ 6 Agricultural Cooperative of Mesolonghi-Nafpaktia, 30200 Mesolonghi, Greece; pakanatas@gmail.com \\ 7 Ministry of Rural Development \& Food, Koniareio Citrus Institute, 20100 Kechries Corinthia, Greece; \\ sgeoponos@gmail.com \\ 8 Department of Weed Science, University of Hohenheim, 70599 Stuttgart, Germany; \\ G.Peteinatos@uni-hohenheim.de \\ * Correspondence: travlos@aua.gr
}

Received: 3 September 2019; Accepted: 4 November 2019; Published: 5 November 2019

\begin{abstract}
Sorghum halepense (L.) Pers is a common and noxious worldwide weed of increasing distribution in many European countries. In the present review, information on the biology, ecology, agricultural, economic and environmental impact of johnsongrass is given, and the current status of this weed in Europe is discussed. Furthermore, special attention is given to the important role of field trials using glyphosate to control weeds in arable and perennial crops in many European countries. Some of the factors which affect control efficacy and should be taken into account are also discussed. Finally, several non-chemical alternative methods (cultural, mechanical, thermal, biological, etc.) for johnsongrass management are also presented. The adoption of integrated weed management (IWM) techniques such as glyphosate use, crop rotation, and deep tillage is strongly recommended to control plant species that originate from both seed and rhizomes.
\end{abstract}

Keywords: Sorghum halepense; johnsongrass; integrated weed management; glyphosate

\section{Johnsongrass Distribution, Ecology and Impacts}

Johnsongrass (Sorghum halepense) is one of the most common and troublesome weeds with a worldwide distribution. It is considered a serious weed in more than 53 countries, causing increases in the costs of production as well as important yield losses in a wide range of field crops including corn, grain sorghum, soybean, sunflower, sugarcane, cotton, pastures and alfalfa but also in several perennial crops [1]. Johnsongrass is also an alternate host of numerous pathogen species [2] and can be toxic to livestock $[3,4]$. Knowledge of the biology, ecology, and agricultural impact of this weed species is necessary to ensure the efficacy and sustainability of control strategies $[5,6]$. 
Its origin remains unclear, but some authors have suggested that it originated from the hybridization of Sorghum arundinaceum and Sorghum propinquum through chromosome doubling (chromosomes: $2 n=4 x=40$ ) [7]. It is now found from latitude $55^{\circ} \mathrm{N}$ to latitude $45^{\circ} \mathrm{S}$, where it infests all continents except Antarctica [8]. It is mostly associated with sites with high moisture, such as along irrigation canals, cultivated fields, field edges, orchards, and pastures [9]; however, it is under water stress conditions that plants originating from rhizomes are more drought-resistant and competitive than crops [10]. S. halepense can survive in diverse ecological habitats. Its widespread distribution in many countries in Europe, including Greece, Spain, Italy, Albania, Bulgaria, Austria, Slovenia, Serbia, Croatia, Bosnia-Herzegovina, Czech Republic, Denmark, France, Belgium, Netherlands, Latvia, Lithuania, Belarus, Poland, Switzerland, UK, Ukraine, Russia, Romania and Hungary [11-21] highlights the importance of that highly invasive species. Lately, researchers reported the spread of this serious weed in many agricultural habitats in Europe [22], while Follak and Essl [18] reported a progressive change of $S$. halepense habitat affiliation and a dispersal to other areas of central Europe, probably and partially due to climate change. Furthermore, modeling has shown that all the main agricultural areas of Europe will become ecologically suitable for $S$. halepense by 2050 [23].

Johnsongrass reduces native species diversity $[24,25]$. Moreover, its hybridization with cultivated Sorghum spp. [26-28] has been reported. Holm et al. [8] suggested that the poor germination and growth of some crops on infested land is the result of toxic exudates from roots or decaying vegetation. This hypothesis has also been supported by more recent studies [29-31]. The latter authors have recorded more allelopathic damage to cotton (up to $86 \%$ of crop loss) than to maize (up to $64 \%$ of loss). A high level of allelopathic activity has also been found in the root exudates of $S$. halepense [32]. Nouri et al. [31] mentioned that extracts of different tissues of johnsongrass reduced the fresh weight of wheat seedlings. In addition, Rout and Chrzanowski [33] suggested that nitrogen-fixing activity is associated with S. halepense and reported that this may enhance the ability of S. halepense to invade and persist by altering fundamental ecosystem properties via changes in soil biogeochemistry. The presence of $S$. halepense in the field can cause allelopathic effects on several subsequent crops like soybean and maize [34,35], and, consequently, the agronomic impacts of this weed cannot be limited only to competition during a single growing season-the allelopathic effects of the roots and residues during one or more growing seasons also have to be taken into account.

Johnsongrass can reproduce via seed through self- or cross-pollination and vegetatively via an extensive rhizome network [36]. Its reproductive ability is enormous since it can produce up to $70 \mathrm{~m}$ of rhizomes per plant in one growing season, and it can produce 28,000 seeds per plant [37] or even more (up to 80,000 seeds per plant [38]). Johnsongrass can disperse by seeds and vegetative organs. Seed production has the greatest potential for the establishment and spread of S. halepense [39], as johnsongrass forms a long-term soil seed bank. However, plants that emerge from rhizomes have higher growth rates, even when they are stressed, and, as a result, these plants are more competitive compared to the seedlings [10]. According to Loddo et al. [40], predictive models based on the effect of temperature on rhizome performance can generate important information about the seasonal dynamics of the plants and the timing of control operations.

Seed dormancy can be a key factor in the seed life span and viability of johnsongrass by enabling its re-establishment after unfavorable growing seasons [41]. Bennett [42] reported on physical dormancy due to the mechanical restriction of the seed coat, which contains tannin compounds that reduce permeability to water. In addition to that, Hamad et al. [43] described dormancy imposed by chemical substances present outside or inside the embryo. Dormancy strongly interacts with environmental factors, such as temperature, humidity and light [44]. For instance, seed exposure to high temperature and light regimes has been shown to be effective in breaking seed dormancy in johnsongrass [45]. All the above-mentioned biological and ecological traits and distributional characteristics of this weed species explain why it is considered a major threat to agricultural production. Hence, it may be argued that further spread could limit the efficient control of johnsongrass in Europe. 
The agronomic and economic impacts of the weed can be highly variable and often reach very high levels, ranking johnsongrass as the world's sixth worst weed [46]. Its effects include severe yield losses in economically important crops including field crops (annual spring crops), vegetables and perennial crops $[1,20,47]$. For instance, in the cotton crop in Turkey, only a single johnsongrass plant per $8 \mathrm{~m}$ of cotton row has been found to decrease yield by $4.82 \%$ and $9.42 \%$ in 1997 and 2002, respectively [48]. In another study, Dogan and Boz [49] reported that a whole season johnsongrass competition caused approximately $65 \%$ of cotton yield losses. In Southern Austria, the invasion of johnsongrass has put risks of yield losses of approximately $40 \%$ for grain maize and pumpkin-oil fields [18], and similar effects have been reported for crops such as the sunflower in Hungary [50]. Similarly, maize without the efficient control of johnsongrass has led to yield reductions of $12-88 \%$ in several countries [51-54]. Kleinbauer [23] classified S. halepense as a medium risk weed for the German and the Austrian regions, while Novák et al. [13] described S. halepense as the 11th most dominant weed species in Hungary. In other countries such as Slovakia, S. halepense has been considered rare in the past, appearing in less than $5 \%$ of areas but lately increasing [55,56]. Vasilakoglou et al. [30] showed that in Greece, cotton growth and yield were reduced due to johnsongrass (at a density of 150 stems $\mathrm{m}^{-2}$ ) season-long interference by $64 \%$ and $86 \%$, respectively. The corresponding maize yield losses were $62 \%$ and $41 \%$, respectively. This study confirmed the different effects of johnsongrass on maize and cotton, which could be merely attributed to the different growth rate and competitive ability of the two crops. In another study conducted by Mitskas et al. [53], johnsongrass plants emerging from rhizomes resulted in yield loss ranging from $76-90 \%$ in maize, while seedlings resulted in $60-77 \%$ yield losses. Consequently, it seems that the origin of johnsongrass (from seed or rhizomes), the time of weed emergence, the crop or even cultivar/hybrid could significantly affect competition and yield loss [5].

In all cases, and despite variability, the impacts of $S$. halepense remain huge, with losses in soybean in countries such as Argentina amounting to $\$ 300$ million per year [57]. Johnsongrass control costs have been evaluated at 165 million Euros, and profit losses have been estimated at 227 million Euros [58]. Indicative of the huge agronomic impacts of johnsongrass is the fact that several methods based on canopy attributes have been developed in order to accurately predict crop yield losses caused by $S$. halepense in crops such as maize and soybean $[59,60]$. In Europe and the rest of the world, johnsongrass is therefore among the most serious weeds; consequently, its adequate control is of major importance.

\section{Aspects of Integrated Management of Johnsongrass}

Integrated weed management systems combine several weed control methods. In particular, the management of johnsongrass requires the effective control of both plants emerged from seeds and plants emerged from rhizomes. Since the rhizome system of johnsongrass is extremely extensive and spreads very quickly in the first year, it is really crucial to take action as early as possible. Thus, killing the below-ground tissues and depleting their carbohydrate stores is usually the primary goal of its chemical control. In a consistent, integrated program preventive, cultural, mechanical, and chemical methods should be used together. It is also crucial to prevent the transport of seeds and rhizomes from infested fields to uninfected fields. However, the adequate control of $S$. halepense is very difficult without the use of herbicides, with repeated treatments being necessary to maintain long term control $[1,49]$. Van Esso and Ghersa [61] evaluated the efficacy of control practices for johnsongrass in soybean and sunflower cropping systems where the timing of cultural and chemical control practices was adjusted to weed phenological stages by using visually estimated indices and with a thermal calendar model to forecast the crucial period for johnsongrass propagation (when the population's rhizome mass is minimal). The results revealed that visually estimated indices had an effect only in the sunflower, while with the thermal calendar, weed infestation was reduced in both cropping systems by more than $90 \%$ in one growing season and johnsongrass was eradicated in two growing seasons [61]. The advantages of using the thermal calendar model to determine the time of herbicide application and the possible influence of the distribution of the rhizome population in the soil profile on the predictions of the model 
were discussed by Ghersa et al. [62]. However, the use of models remains uncommon, and johnsongrass has already developed resistance to several herbicides [63], with the majority of them (more than $85 \%$ ) being selective (mostly ACCase and ALS inhibitors). Consequently, the role of other selective and especially non-selective herbicides (such as glyphosate) could be significant, especially under the view of reduced or minimum tillage systems which have been widely adopted lately. In systems like these, weed control is mostly based on the use of non-selective herbicides such as glyphosate. In the section below, the focus is narrowed to glyphosate as an important tool for the effective control of johnsongrass in Europe, mainly due to its high efficacy before crop establishment or after crop harvest and the absence of any glyphosate resistance cases [63]. Some other available chemical options are also discussed.

\subsection{Chemical Control of Johnsongrass with Emphasis to Glyphosate}

Johnsongrass management in European countries has been mainly based on the POST-emergent application of sulfonylurea and other ALS and ACCase inhibiting herbicides; however, due to the lack of other modes of action and the overuse of herbicides with the same mode of action, herbicide-resistant biotypes have occurred and dramatically increased across Europe [63]. The control of both the seedlings and rhizomes of johnsongrass has been achieved in many crops when sprayed with products containing glyphosate [64]. Globally, many studies have confirmed the high efficacy of glyphosate against $S$. halepense, which is typically used as a late-summer or fall treatment for postharvest johnsongrass control [65-67]. Tillage has not been found to be necessary to obtain the effective control of $S$. halepense with foliar applications of glyphosate [68]. Furthermore, in a study conducted to determine the duration of time after herbicide treatment required to render johnsongrass physiologically noncompetitive, Ferrell et al. [69] concluded that glyphosate most readily rendered S. halepense noncompetitive (4.3 days after treatment) compared to other herbicides (nicosulfuron, imazapic and clethodim), which also resulted in high efficacy against johnsongrass.

Below, a brief selection of studies completed in several European countries illustrates the significant role of glyphosate for the control of S. halepense. In Hungary, stubble treatment with glyphosate (mainly in the middle of July) is a common practice when S. halepense appears. That method allows glyphosate to control the rhizomes of S. halepense, but it does not affect the seeds. As Kukorelli showed, three to four years after the glyphosate stubble treatment, the rhizome form of $S$. halepense spreads again in the fields, and it is consequently necessary for the treatment to be repeated. As mentioned above, johnsongrass management has mainly been based on the POST application of sulfonylurea herbicides like nicosulfuron, foramsulfuron and rimsulfuron. However, the multiyear cropping systems of maize and the large number of sulfonylurea applications has resulted in the selection of herbicide-resistant biotypes. The high efficacy of glyphosate to control ALS-resistant johnsongrass has also become evident. The results of a study conducted by Kukorelli in 2017 (personal communication) have shown that a rate of 1.44-1.8 $\mathrm{kg}$ a.e./ha of glyphosate provides the highest efficacy against $S$. halepense in stubble, with new plants emerging only from seed.

In Spain, johnsongrass tripled its total distribution in 2010 compared to 2009 in the absence of control measures [70]. Glyphosate is very effective in controlling $S$. halepense at the standard recommended rate ( $2.16 \mathrm{~kg}$ a.e./ha) when plants are higher than $40 \mathrm{~cm}$. It has to be noted that in September and October, a glyphosate rate of $1.8 \mathrm{~kg}$ a.e./ha is adequate for johnsongrass control due to the fact that the plant translocates and assimilates the herbicide towards the rhizomes [69,70]. The first reports on the low efficacy of ALS inhibitors against S. halepense in Spain were recorded in 2014. Several dose-response studies were conducted, and resistance was confirmed in vitro. In more than 20 fields studied, a mutation in the position Trp574 of the ALS gene of S. halepense was found. This point mutation causes resistance to all ALS inhibitors, and, for that reason, crop rotation was one of the main recommendations to the Spanish farmers. The Committee for Preventing Weed Resistance (CPRH) to herbicides published a booklet in 2016 (semh.net/wpcontent/uploads/2015/09/Diptico-Sorghum-halepense.pdf) with several recommendations to achieve a sustainable management of $S$. halepense. One noticeable recommendation 
by the CPRH was to shorten the crop cycle in order to be able to harvest earlier and spray glyphosate on johnsongrass patches before the winter. Johnsongrass is also one of the most troublesome weeds in Serbian field crop production [71]. The continuous use of some ALS and ACCase inhibitors over many years in monocultures of soybean, maize and other crops has resulted in the selection of johnsongrass biotypes with multiple resistances [72]. In particular, it has been estimated that the ALS-resistant populations of $S$. halepense are infesting more than 150,000 ha of crop fields in Serbia, and control measures are urgently needed. According to Malidža et al. [73], the application of glyphosate after the harvest of small grains and subsequent soil tillage are highly recommended since they could be very effective against these resistant biotypes. In Greece (like in other Mediterranean countries), johnsongrass is a serious and troublesome weed in all the summer crops (e.g., maize, cotton, sunflower, soybean, and sugar beet) and perennial crops (e.g., olives, vines, citrus, and apple) causing yield losses up to $90 \%$ and $45 \%$, respectively (Travlos, unpublished data from recent surveys). Several biotypes have been confirmed to be ALS- and ACCase-resistant, making the control of S. halepense even more challenging. In recent experiments, it has been shown that with the use of short growth cycle maize hybrids (FAO maturity group $<400$ ), subsequent deep tillage and two applications of glyphosate (one in the stubble (summer) and one after plowing, rhizome drying and late sprouting (autumn)), the density of the weed is significantly reduced for the next few years. In a field trial conducted in olives in Greece, it was shown that glyphosate was very effective against johnsongrass, giving $80 \%$ control even at a rate of $1440 \mathrm{~g}$ ae/ha [74]. Moreover, previous studies have shown that the application of glyphosate with adjuvants after seedhead emergence can significantly reduce S. halepense regrowth [75]. In a study conducted with a stale seedbed treatment of glyphosate in Turkey, johnsongrass was successfully controlled [64]. In particular, the cover and biomass of the weed were reduced by $61-75 \%$ and $60-69 \%$, respectively after glyphosate application at $2.8 \mathrm{~kg}$ a.e./ha [64]. Similar results were also obtained in ongoing stale seedbed field trials in Greece (in soybean and groundnut) by Travlos et al. (unpublished data).

\subsection{Non-Chemical Control of Johnsongrass}

In organic and other low-external-input (LEI) farming practices, the approach to weed management involves the whole cropping system [76] and a long-term approach. Therefore, several non-chemical weed control measures need to be integrated with cultural practices because one single method cannot be satisfactory, and the weed often continues to cause significant yield losses [77].

Prior to the extended use of herbicides, planting pasture grasses in an area with a serious infestation has been shown in some cases to be an effective method against johnsongrass. These grasses have then been repeatedly mowed or grazed during the first season, resulting in the shallow rooting of johnsongrass [78]. This system was carried out for at least a year and was followed by shallow tillage along with using a cash crop or a bare fallow to kill the weakened perennial weeds. Multiple passes of a cultivator with sweeps can bring rhizomes to the soil surface during the summer months, allowing them to dry out $[79,80]$. Mowing and tillage can be combined in order to control johnsongrass [81]. Warwick and Black [36] indicated that mowing can also be an alternative and effective management technique that reduces the growth of rhizomes and seed onset. The optimum timing for mechanical weed control is influenced by the competitive ability of the crop [82] and the growth stage of the weeds [83]. Hand hoes, push hoes and hand-weeding are still used in order to prevent the weed from spreading and dominating [84]. Hand-weeding may also be used after mechanical inter-row weeding to control weeds left in the crop rows [85].

In general, multiple tillage operations can deplete johnsongrass stands if seedlings and sprouts are regularly uprooted and rootstocks are desiccated. Sharp tools set at the proper depth and operated to overlap are needed to uproot all the johnsongrass. Repeated and deep summer tillage before S. halepense grows to a height of $20 \mathrm{~cm}$ reduces stands and sometimes eradicates it, while usual seedbed preparations retard the spread of johnsongrass but do not affect its stands [86]. Growing early-maturing crops, plowing immediately after harvest, and precise tilling are common methods to 
break up rhizomes and weaken johnsongrass stands in cultivated areas. Early crop sowing has also been associated with lower competition by S. halepense in maize and cotton [87]. Johnsongrass responds to tillage like most perennial weeds. Intensive tillage is needed, as moderate tillage only breaks and spreads rhizomes and allows johnsongrass to thrive. Johnsongrass spreads relatively slowly in true no-till regimes; however, after some time, infestations may still become severe [88].

Deep plowing during late fall or early winter seems to significantly reduce johnsongrass stands. Where possible, plowing should be conducted in a way to bring the majority of rhizomes to the surface and expose them to winter freeze [88]. It is believed that continuous cultivation throughout the winter is particularly effective in controlling johnsongrass, although most fields are usually too wet [89]. Additionally, deep disking throughout the summer can control johnsongrass-especially during dry summers [1]. The effectiveness of frequent disking is directly related to rhizome dehydration [90], while rhizome depth has already been recognized as the critical factor in the winter survival of S. halepense [91].

Grazing has also been recognized as an effective method for the adequate control of johnsongrass. In addition, this technique makes the weed more vulnerable to other methods [92]. Pasturing has long been recognized as a method of controlling johnsongrass, but effective control from pasturing usually requires two or more seasons. In general, frequent grazing for two or more years weakens johnsongrass plants because rhizomes tend to be formed near the soil surface [89]. Geese are sometimes used to graze johnsongrass in cotton. The geese feed on the young grass without injuring cotton. Best results are obtained when both the grass and cotton plants are small (johnsongrass height $<13 \mathrm{~cm}$ ) and before the hottest part of the season. According to Hauser and Arle [92], the control of S. halepense requires a geese density at a rate of 1-3 per acre, depending on the amount of grass present in the field. Cattle have been also used to graze johnsongrass and other weeds in cotton without any significant reduction of the johnsongrass stand [86]. Moreover, major risks of poisoning are associated with this weed, mostly in cattle and sheep [20].

Cultural weed control practices were used for the control of johnsongrass before the extended use of herbicides [93]. The growth and reproduction of a troublesome weed species like johnsongrass may be actively discouraged by introducing several crops and practices into a rotation $[14,94,95]$. The inclusion of cover crops in the rotation also suppresses weed development [74]. An effective crop rotation consists two-to-four years of alfalfa, two years of cotton (or other row crop), and one or two years of small grain. If the infestation of johnsongrass is heavy, either pasture or summer fallow and disking or plowing frequently during the summer can be effective $[92,96]$. Alfalfa and other frequently mowed or grazed crops grown for three or more consecutive years deplete johnsongrass seed stocks in the soil [86]. Several Brassicaceae species can be used as part of the rotation or as cover crops against johnsongrass [14]. DeGregorio and Ashley [97,98] and Else and Ilnicki [99] found that clover mulches can provide weed control comparable to commercial herbicide programs in maize, sweet corn and snap beans. Another cultural method is the application of fertilizers along with or near the crop row in order to increase the uptake of nutrients by the crop and their competitive ability against weeds such as johnsongrass [100]. Crop row spacing can be also modified and used as an additional cultural method against $S$. halepense. For instance, Bendixon (1988) recorded a significantly lower density of johnsongrass in soybean seeded in $25 \mathrm{~cm}$ rows compared with those of $76 \mathrm{~cm}$ [101].

Johnsongrass, like other perennial species, has also been documented as being susceptible to solarization [102-104]. To maximize control and reduce the regrowth of weeds at the edges of the fields a full coverage with polyethylene is suggested [102]. Law et al. [105] showed that solarization with or without previous tillage reduced johnsongrass populations by more than $56 \%$ compared with the untreated plots (bare fallow). Flaming has also been used against johnsongrass; however, many applications are required, and treatments needed to be done at specific weed and crop growth stages [92]. Flooding soil with 5-10 cm of water for one-to-two weeks is also a good alternative way to control johnsongrass plants and rhizomes [89,106]; however, it is not always feasible. Andújar et al. [95] 
also found that furrow irrigation systems allowed for the establishment of large patches of johnsongrass with a high plant density, while patches were smaller and less dense with the sprinkler irrigation system.

Millhollon [107], Chandramohan and Charudattan [108] and Tilley and Walker [109] have highlighted the potential of several biological agents for the control of johnsongrass, but more research is obviously needed towards the development of bioherbicides. Moreover, Bridges and Chandler [110] found significant differences in the competitiveness between three cotton cultivars against johnsongrass, and more research is necessary in order to evaluate more crop varieties and hybrids under different soil and climatic conditions [5].

\section{Conclusions}

Conclusively, information on the biology, ecology, agricultural and economic impact of johnsongrass is necessary to increase the sustainability of control strategies. High growth rates coupled with high biomass production both above ground and in rhizomes, seed dormancy, prolific seed production, adaptability over a wide range of soil and climatic conditions, strong allelopathic potential and competitive ability, as well as resistance to several ALS and ACCase inhibiting herbicides, make $S$. halepense a major threat to European agricultural production. Changes in crop management practices, improved tillage management, and diverse chemical-based techniques are among the best options for the effective control of $S$. halepense. A number of these effective techniques could be used in combination with herbicides. Glyphosate is an important tool for the effective control of johnsongrass in Europe, either before crop establishment or after crop harvest, while the absence of glyphosate resistance up to now is another advantage which should be kept as long as possible by the means of the adoption of integrated weed management methods and not an overreliance of a single method. More studies are needed on long-term management strategies that integrate chemical and non-chemical approaches in a sustainable manner in order to prevent the widespread invasion of this troublesome weed.

Author Contributions: I.S.T., J.M.M., G.K., G.M., M.N.D., N.C., N.A., P.J.K., S.Z. and G.P. contributed equally, reviewed the literature and wrote the paper.

Funding: This research was funded by Bayer Agriculture BVBA, grant number 140319.

Conflicts of Interest: The authors declare no conflict of interest.

\section{References}

1. Travlos, I.S.; Bilalis, D.J.; Katsenios, N.; De Prado, R. Sustainable weed control in vineyards. In Weed Control: Sustainability, Hazards, and Risks in Cropping Systems Worldwide; Korres, N.E., Burgos, N.R., Duke, S.O., Eds.; CRC Press: Boca Raton, FL, USA, 2018; pp. 526-542. [CrossRef]

2. Parsons, W.T. Noxious Weeds of Australia; Parsons, W.T., Cuthbertson, E.G., Eds.; Inkata Press: Melbourne, Australia, 1992.

3. Nóbrega, J., Jr.; Riet-Correa, F.; Medeiros, R.M.T.; Dantas, A.F.M. Intoxicação por Sorhgum halepense (Poaceae) em bovinos no semi-árido. Pesquisa Veterinária Brasileira 2006, 26, 201-204. [CrossRef]

4. Burrows, G.E.; Tyrl, R.J. Toxic Plants of North. America: Burrows/Toxic Plants of North. America; Wiley-Blackwell: Oxford, UK, 2012. [CrossRef]

5. Travlos, I.S.; Economou, G.; Kanatas, P.J. Corn and barnyardgrass competition as influenced by relative time of weed emergence and corn hybrid. Agron. J. 2011, 103, 1. [CrossRef]

6. Chauhan, B.S. Weed ecology and weed management strategies for dry-seeded rice in Asia. Weed Technol. 2012, 26, 1-13. [CrossRef]

7. Ng'uni, D.; Geleta, M.; Fatih, M.; Bryngelsson, T. Phylogenetic analysis of the genus Sorghum based on combined sequence data from cpDNA regions and ITS generate well-supported trees with two major lineages. Ann. Bot. 2010, 105, 471-480. [CrossRef] [PubMed]

8. Holm, L.G.; Plucknett, D.L.; Pancho, J.V.; Herberger, J.P. The World's Worst Weeds; University Press: Honolulu, HI, USA, 1977; p. 609. 
9. Chambers, N.; Hawkins, T.O. Invasive Plants of the Sonoran Desert, A Field Guide; Sonoran Institute, Environmental Education Exchange, National Fish and Wildlife Foundation: Tucson, AZ, USA, 2002; p. 120.

10. Acciaresi, H.A.; Guiamet, J.J. Below- and above-ground growth and biomass allocation in maize and Sorghum halepense in response to soil water competition: Maize and Sorghum halepense in competition for water. Weed Res. 2010, 50, 481-492. [CrossRef]

11. de Almeida, J.D.; Freitas, H. Exotic naturalized flora of continental Portugal-A reassessment. Bot. Complut. 2006, 30, 117-130.

12. Pascal, M.; Lorvelec, O.; Vigne, J.-D. Invasions Biologiques et Extinctions: 11000 ans D'histoire des Vertébrés en France; Coédition Belin - Quæ: Paris, France, 2006.

13. Novák, R.; Dancza, I.; Szentey, L.; Karamán, J.; Béres, I.; Kazinczi, G.; Gólya, G. Arable Weeds of Hungary. Fifth National Weed Survey (2007-2008); Ministry of Agriculture and Rural Development: Budapest, Hungary, 2009 ; p. 95.

14. Uremis, I.; Arslan, M.; Uludag, A.; Sangun, M. Allelopathic potentials of residues of 6 brassica species on johnsongrass [Sorghum halepense (L.) Pers.]. Afr. J. Biotechnol. 2009, 8, 3497-3501.

15. Vilà, M.; Basnou, C.; Gollasch, S.; Josefsson, M.; Pergl, J.; Scalera, R. One hundred of the most invasive alien species in Europe. In Handbook of Alien Species in Europe; Springer: Dordrecht, The Netherlands, 2009; pp. 265-268. [CrossRef]

16. Vrbničanin, S.; Malidža, G.; Stefanović, L.; Elezović, I.; Stanković-Kalezić, R.; Marisavljević, D.; Jovanović-Radovanov, K.; Pavlović, D.; Gavrić, M. Distribution of some harmful, invasive and quarantine weeds on the territory of Serbia, Part III: Spatial distribution and frequency of eight weeds species. Biljni Lekar 2009, 37, 21-30.

17. Bernacki, Z. Changes in the balance between $\mathrm{C} 3$ and $\mathrm{C} 4$ plants expected in Poland with the global change. Ecol. Quest. 2012, 16, 59. [CrossRef]

18. Follak, S.; Essl, F. Spread dynamics and agricultural impact of Sorghum halepense, an emerging invasive species in Central Europe: Spread dynamics and impact of Sorghum halepense. Weed Res. 2013, 53, 53-60. [CrossRef]

19. Ortiz, R.; Contreras, J.; Ruiz, A.; Sanz, M.; Romero, M.; Gordillo, M.; Taberner Palou, A.; Urbano Fuentes-Guerra, J.M. Malas hierbas preocupantes en España. In Proceedings of the XV Congreso de la Sociedad Española de Malherbología: La Malherbología y la Transferencia Tecnológica, Sevilla, Spain, 19-22 October 2015; pp. 497-503.

20. Peerzada, A.M.; Ali, H.H.; Hanif, Z.; Bajwa, A.A.; Kebaso, L.; Frimpong, D.; Iqbal, N.; Namubiru, H.; Hashim, S.; Rasool, G.; et al. Eco-biology, impact, and management of Sorghum halepense (L.) Pers. Biol. Invasions 2017. [CrossRef]

21. CABI. Invasive Species Compendium. Available online: https://www.cabi.org/isc/datasheet/50624 (accessed on 31 May 2019).

22. Weber, E.; Gut, D. A survey of weeds that are increasingly spreading in Europe. Agron. Sustain. Dev. 2005, 25, 109-121. [CrossRef]

23. Kleinbauer, I.; Dullinger, S.; Klingenstein, F.; May, R.; Nehring, S.; Essl, F. Ausbreitungspotenzial Ausgewählter Neophytischer Gefäßpflanzen unter Klimawandel in Deutschland und Österreich: Ergebnisse aus dem F+ E-Vorhaben FKZ 80682 330. Bundesamt für Naturschutz, 2010. Available online: http://www.bfn.de/0502_ artenschutz.html (accessed on 20 March 2012).

24. Pál, R. Invasive plants threaten segetal weed vegetation of south Hungary. Weed Technol. 2004, 18, 1314-1318. [CrossRef]

25. Rout, M.E.; Chrzanowski, T.H.; Smith, W.K.; Gough, L. Ecological impacts of the invasive grass Sorghum halepense on native tallgrass prairie. Biol. Invasions 2013, 15, 327-339. [CrossRef]

26. Arriola, P.E.; Ellstrand, N.C. Crop-to-weed gene flow in the genus Sorghum (Poaceae): Spontaneous interspecific hybridization between johnsongrass, Sorghum halepense, and crop sorghum, S. bicolor. Am. J. Bot. 1996, 83, 1153-1159. [CrossRef]

27. Dweikat, I. A Diploid, Interspecific, fertile hybrid from cultivated sorghum, Sorghum bicolor, and the common johnsongrass weed Sorghum halepense. Mol. Breed. 2005, 16, 93-101. [CrossRef]

28. Grenier, C.; Ejeta, G. Sorghum and its weedy hybrids. In Crop Ferality and Volunteerism; Gressel, J., Ed.; CRC Press: Boca Raton, FL, USA, 2005; pp. 123-135. 
29. Torma, M.; Bereczki-Kovács, E. Study of the allelopathic effect of Cirsium arvense (L.) Scop and Sorghum halepense (L.) Pers. Magyar Gyomkutatás és Technológia 2004, 5, 35-41.

30. Vasilakoglou, I.; Dhima, K.; Eleftherohorinos, I. Allelopathic potential of bermudagrass and johnsongrass and their interference with cotton and corn. Agron. J. 2005, 97, 303-313.

31. Nouri, H.; Talab, Z.A.; Tavassoli, A. Effect of weed allelopathic of sorghum (Sorghum halepense) on germination and seedling growth of wheat, Alvand cultivar. Ann. Biol. Res. 2012, 3, 1283-1293.

32. Czarnota, M.A.; Rimando, A.M.; Weston, L.A. Evaluation of Root Exudates of Seven Sorghum Accessions. J. Chem. Ecol. 2003, 29, 2073-2083. [CrossRef]

33. Rout, M.E.; Chrzanowski, T.H. The invasive Sorghum halepense harbors endophytic N2-fixing bacteria and alters soil biogeochemistry. Plant Soil 2009, 315, 163-172. [CrossRef]

34. Soufan, R.; Almouemar, A. Allelopathic effects of some weeds on growth of maize (Zea mays L.). In Proceedings of the XIIIème Colloque International sur la Biologie des Mauvaises Herbes, Dijon, France, 8-10 September 2009; pp. 414-421.

35. Ştef, R.; Cărăbeţ, A.; Grozea, I.; Radulov, I.; Manea, D.; Berbecea, A. Allelopathic effects produced by johnson grass extracts over germination and growth of crop plants. Bull. Univ. Agric. Sci. Vet. Med. Cluj-Napoca Agric. 2015, 72, 239-245. [CrossRef]

36. Warwick, S.I.; Black, L.D. The Biology of Canadian Weeds: 61. Sorghum halepense (L.) PERS. Can. J. Plant Sci. 1983, 63, 997-1014. [CrossRef]

37. Monaghan, N. The biology of Johnson grass (Sorghum halepense). Weed Res. 1979, 19, 261-267. [CrossRef]

38. Anderson, W.P. Weed Science: Principles and Applications, 3rd ed.; West Publishing Company: St. Paul, MN, USA, 1996; p. 388.

39. Keeley, P.E.; Thullen, R.J. Influence of Planting Date on the Growth of Johnsongrass (Sorghum halepense) from Seed. Weed Sci. 1979, 27, 554-558. [CrossRef]

40. Loddo, D.; Masin, R.; Otto, S.; Zanin, G. Estimation of base temperature for Sorghum halepense rhizome sprouting: Rhizome sprouting in Sorghum halepense. Weed Res. 2012, 52, 42-49. [CrossRef]

41. Huang, W.Z.; Hsiao, A.I. Factors affecting seed dormancy and germination of Johnsongrass, Sorghum halepense (L.) Pers. Weed Res. 1987, 27, 1-12. [CrossRef]

42. Bennett, H.W. Johnsongrass, Carpetgrass, and other Grasses for the Humid South. In Forages; Iowa State University Press: Ames, IA, USA, 1973; pp. 286-293.

43. Hamada, A.; Koch, W.; Hamdoun, A.; Kunisch, M.; Sauerborn, J. Effect of temperature, light, and simulated drought on the germination of some weed species from the Sudan. Angew. Bot. 1993, 7, 52-55.

44. Singh, S.; Singh, M. Effect of temperature, light and $\mathrm{pH}$ on germination of twelve weed species. Indian J. Weed Sci. 2009, 41, 113-126.

45. Podrug, A.; Gadžo, D.; Muminović, Š.; Grahić, J.; Srebrović, E.; Đikić, M. Dormancy and germination of johnsongrass seed (Sorghum halepense (L.) Pers.). Herbol. Int. J. Weed Res. Control 2014, 2. [CrossRef]

46. Valverde, B.; Gressel, J. Dealing with the Evolution and Spread of Sorghum Halepense Glyphosate Resistance in Argentina. Consultancy Report to SENASA, Buenos Aires. 2006. Available online: http://www.sinavimo. gov.ar/files/senasareport2006.pdf (accessed on 14 January 2009).

47. Kegode, G.O.; Bishnoi, U.R.; Mays, D.A. The Influence of Johnsongrass Infestation and Nitrogen Rates on Grain Sorghum. J. Agron. Crop Sci. 1994, 172, 242-246. [CrossRef]

48. Uludag, A.; Gozcu, D.; Rusen, M.; Sadet Guvercin, R.; Demir, A. The effect of johnsongrass (Sorghum halepense (L.) Pers.) densities on cotton yield. Pak. J. Biol. Sci. 2007, 10, 523-525. [CrossRef] [PubMed]

49. Dogan, M.; Boz, Ö. The concept of reduced herbicide rates for the control of johnsongrass (Sorghum halepense (L) Pers.) in cotton during the critical period for weed control/Das Konzept reduzierter Herbizidaufwandmengen für die Bekämpfung von Sorghum halepense (L.) Pers. in Baumwolle unter Berücksichtigung der Kritischen Periode. Zeitschrift für Pflanzenkrankheiten und Pflanzenschutz. J. Plant Dis. Prot. 2005, 71-79.

50. Dobszai-Toth, V. A Fenyercirok (Sorghum halepense L. Pers.) Jelentosege, Biologiaja, Kartetele es Vegyszeres Gyomirtasanak Lehetosegei. Ph.D. Thesis, 2010.

51. Mikulas, J.; Sule, S. Bacterial leaf spot of Johnson grass caused by Pseudomonas syringae. Acta Phytopathol. Acad. Sci. Hung. 1979, 14, 83-87.

52. Gubbiga, N.G.; Worsham, A.D.; Coble, H.D.; Lemons, R.W. Effect of nicosulfuron on johnsongrass (Sorghum halepense) control and corn (Zea mays) performance. Weed Technol. 1995, 9, 574-581. [CrossRef] 
53. Mitskas, M.B.; Tsolis, C.E.; Eleftherohorinos, I.G.; Damalas, C.A. Interference between corn and johnsongrass (Sorghum halepense) from seed or rhizomes. Weed Sci. 2003, 51, 540-545. [CrossRef]

54. Kukorelli, G.; Reisinger, P.; Adamszki, T. Effective control against perennial and annual monocotyledon weed species in cycloxydim-resistant maize. In Proceedings of the 15th EWRS Symposium, Kaposvar, Hungary, 11-15 July 2010.

55. Májeková, J.; Zaliberová, M. Invasive and expansive plant species in Slovakian agrocenoses. Biodivers. Res. Conserv. 2008, 9-10, 51-56.

56. Kropáč, Z.; Mochnacký, S. Contribution to the segetal communities of Slovakia. Thaiszia J. Bot. 2009, 19, 145-211.

57. Colbert, B. Johnsongrass, a major weed in soybeans. Hacienda 1979, 74, 21-35.

58. Gunes, E.; Uludag, A.; Uremis, I. Economic impact of johnsongrass (Sorghum halepense [L.] Pers.) in cotton production in Turkey. J. Plant Dis. Prot. 2008, 21, 515-520.

59. Ghersa, C.M.; Martinez-Ghersa, M.A. A field method for predicting yield losses in maize caused by johnsongrass (Sorghum halepense). Weed Technol. 1991, 5, 279-285. [CrossRef]

60. Vitta, J.I.; Satorre, E.H.; Leguizamon, E.S. Using canopy attributes to evaluate competition between Sorghum halepense (L.) Pers. and soybean. Weed Res. 1994, 34, 89-97. [CrossRef]

61. Van Esso, M.L.; Ghersa, C.M. Improving johnsongrass (Sorghum halepense) control in soybean and sunflower cropping systems. Weed Sci. 1993, 41, 107-113. [CrossRef]

62. Ghersa, C.M.; Satorre, E.H.; Esso, M.L.; Pataro, A.; Elizagaray, R. The use of thermal calendar models to improve the efficiency of herbicide applications in Sorghum halepense (L.) Pers. Weed Res. 1990, 30, 153-160. [CrossRef]

63. Heap. The International Survey of Herbicide Resistant Weeds. Available online: http://www.weedscience.org/ (accessed on 28 May 2019).

64. Dogan, M.N.; Ünay, A.; Boz, Ö.; Ögüt, D. Effect of pre-sowing and pre-emergence glyphosate applications on weedsin stale seedbed cotton. Crop Prot. 2009, 28, 503-507. [CrossRef]

65. Jeffery, L.S.; English, J.R.; Connell, J. The Effects of fall application of glyphosate on corn (Zea mays), soybeans (Glycine max), and johnsongrass (Sorghum halepense). Weed Sci. 1981, 29, 190-195. [CrossRef]

66. Culpepper, A.S.; York, A.C.; Batts, R.B.; Jennings, K.M. Weed Management in Glufosinate- and Glyphosate-Resistant Soybean (Glycine max). Weed Technol. 2000, 14, 77-88. [CrossRef]

67. Griffin, J.L.; Miller, D.K.; Salassi, M.E. Johnsongrass (Sorghum Halepense) control and economics of using glyphosate-resistant soybean in fallowed sugarcane fields. Weed Technol. 2006, 20, 980-985. [CrossRef]

68. Glenn, S.; Peregoy, R.S.; Hook, B.J.; Heimer, J.B.; Wiepke, T. Sorghum halepense (L.) Pers. control with foliar-applied herbicides in conventional and no-tillage soyabeans. Weed Res. 1986, 26, 245-250. [CrossRef]

69. Ferrell, J.A.; Earl, H.J.; Vencill, W.K. The effect of selected herbicides on $\mathrm{CO}_{2}$ assimilation, chlorophyll fluorescence, and stomatal conductance in johnsongrass (Sorghum halepense L). Weed Sci. 2003, 51, $28-31$. [CrossRef]

70. Barroso, J.; San Martín, C.; Andújar, D.; Hernaiz, P.; Campos, D.; Martín, J.; Dorado, J. Competencia entre la cañota (Sorghum halepense) y el maíz grano. In Proceedings of the XIII Congreso Nacional de Malherbología, La Laguna, Spain, 22-24 November 2011; pp. 183-186.

71. Malidža, G.; Rajković, M.; Vrbničanin, S.; Božić, D. Cross-resistance of Sorghum halepense to ALS inhibitors in Serbia and implications for resistance management. Book of Abstracts of the VII Congress on Plant Protection: Integrated Plant Protection Knowledge-Based Step Towards Sustainable Agriculture. For. Landsc. Archit. 2014, 143-144.

72. Malidža, G.; Rajković, M. First case of multiple resistance of Johnsongrass (Sorghum halepense (L.) Pers.) to ALS- and ACCase-inhibiting herbicides in Serbia. In Proceedings of the Perspectives and Challenges of Weed Control and Weed Resistance to Herbicide in Europe, Antalya, Turkey, 29-30 November 2018.

73. Malidža, G.; Bekavac, G.; Rajković, M.; Vasić, M. Advantages and new challenges for use of cycloxydim-tolerant maize. In Proceedings of the EWRS Working Group Herbicide Tolerant Varieties, Novi Sad, Serbia, 29-31 May 2017.

74. Travlos, I.S.; Kanatas, P.J.; Rapti, H.; Papastylianou, P.; Hatziagapi, V. Herbicide resistance of weeds in olive groves and crucial points of integrated weed management. In Proceedings of the 20th Conference of Weed Science Society of Greece, Agrinio, Greece, 4-6 April 2019; pp. 92-93. 
75. Miller, D.K.; Griffin, J.L.; Richard, E.P. Johnsongrass (Sorghum halepense) Control and Rainfastness with Glyphosate and Adjuvants. Weed Technol. 1998, 12, 617-622. [CrossRef]

76. Liebman, M.; Davis, A.S. Integration of soil, crop and weed management in low-external-input farming systems. Weed Res. 2000, 40, 27-47. [CrossRef]

77. Rasmussen, J. Can high densities of competitive weeds be controlled efficiently by harrowing or hoeing in agricultural crops? In Proceedings of the Communications 4th International Conference IFOAM, Non-Chemical Weed Control, Dijon, France, 5-9 July 1993; pp. 85-89.

78. McWhorter, C.G. History, biology, and control of johnsongrass. Rev. Weed Sci. 1989, 4, 85-121.

79. Hunt, T. Johnson grass eradication. In Report of the College of Agriculture and the Agricultural Experiment Station of the University of California; University of California Press: Berkeley, CA, USA, 1915.

80. Talbot, M.W. Johnson Grass as a Weed; U.S. Dept. of Agriculture: Washington, DC, USA, 1928; Volume 1537.

81. Cates, J.S.; Spillman, W.J. A Method of Eradicating Johnson Grass; US Dept. of Agriculture: Washington, DC, USA, 1907.

82. Turner, R.; Lennartsson, M.; Bond, W.; Grundy, A. Organic weed control-getting it right in time. In Proceedings of the Brighton Crop Protection Conference Weeds, Brighton, UK, 15 November 1999; pp. 969-974.

83. Pullen, D.W.M.; Cowell, P.A. An evaluation of the performance of mechanical weeding mechanisms for use in high speed inter-row weeding of arable crops. J. Agric. Eng. Res. 1997, 67, 27-34. [CrossRef]

84. Marshall, T. Weed control in organic farming systems. In Proceedings of the 1st International Weed Control Congress, Melbourne, Australia, 17-21 February 1992; pp. 311-314.

85. Ionescu, N.; Perianu, A.; Popescu, A.; Sarpe, N.; Roibu, C. Weed control in corn and soybean crops by mechanical and manual management practices. In Proceedings of the Xe Colloque International Sur la Biologie Des Mauvaises Herbes, Dijon, France, 11-13 September 1996; pp. 359-365.

86. Arle, H.F.; Everson, E.H. Johnson Grass Control; College of Agriculture, University of Arizona: Tucson, AZ, USA, 1955.

87. Vidotto, F.; Fogliatto, S.; Milan, M.; Ferrero, A. Weed communities in Italian maize fields as affected by pedo-climatic traits and sowing time. Eur. J. Agron. 2016, 74, 38-46. [CrossRef]

88. Johnson, B.; Kendig, A.; Smeda, R.; Fishel, F.; Johnson, B.; Kendig, A.; Smeda, R.; Fishel, F. Johnson grass control. In Weed Identification and Herbicide Injury Guide for Corn and Soybean; University of Missouri Extension: Columbia, MO, USA, 1997.

89. McWhorter, C.G. Growth and Development of Johnsongrass Ecotypes. Weed Sci. 1971, 19, 141-147. [CrossRef]

90. McWhorter, C.G.; Hartwig, E.E. Effectiveness of Preplanting Tillage in Relation to Herbicides in Controlling Johnsongrass for Soybean Production. Agron. J. 1965, 57, 385. [CrossRef]

91. Warwick, S.I.; Phillips, D.; Andrews, C. Rhizome depth: The critical factor in winter survival of Sorghum halepense (L.) Pers. (Johnson grass). Weed Res. 1986, 26, 381-388. [CrossRef]

92. Hauser, E.W.; Arle, H.F. Johnson Grass as a Weed; Farmers' Bulletin No. 1537; US Dept. of Agriculture: Washington, DC, USA, 1958.

93. Nalewaja, J.D. Cultural practices for weed resistance management. Weed Technol. 1999, 13, 643-646. [CrossRef]

94. Karlen, D.L.; Varvel, G.E.; Bullock, D.G.; Cruse, R.M. Crop Rotations for the 21st Century. Adv. Agron. 1994, $53,1-45$.

95. Andújar, D.; Rueda-Ayala, V.; Dorado, J.; Gerhards, R.; Fernández-Quintanilla, C. Multivariate Analysis of the Agricultural Management Presence of Sorghum halepense (L.) Pers. Relationships in Maize Crops. Gesunde Pflanzen 2014, 66, 17-22. [CrossRef]

96. Hintzsche, E.; Wittmann, C. L'influence de la rotation et du travail du sol sur les infestations par les adventices en grandes cultures. In Proceedings of the IX è Colloque International sur la Biologie des Mauvaise Herbes, Dijon, France, 16-18 September 1992; pp. 139-145.

97. DeGregorio, R.; Ashley, R. Screening Living Mulches and Cover Crops for Weed Suppression in No Till Sweet Corn. Proc. Ann. Meet.-Northeast. Weed Sci. Soc. (USA) 1985, 39, 80-84.

98. DeGregorio, R.; Ashley, R. Screening Living Mulches/Cover Crops for No-till Snap Beans. Proc. Ann. Meet.-Northeast. Weed Sci. Soc. (USA) 1986, 39, 80-84.

99. Else, M.; Ilnicki, R. Crops and Mulch Systems Effect upon Weeds in Corn. Weed Sci. Soc. Am. 1989, $29,68$.

100. Rasmussen, K. Can slurry injection improve the selectivity of weed harrowing in cereals? In Proceedings of the 4th Workshop of the EWRS Working Group on Physical and Cultural Weed Control, Elspeet, The Netherlands, 20-22 March 2000; pp. 33-34. 
101. Bendixon, L.E. Soybean (Glycine max) competition helps herbicides control johnsongrass (Sorghum halepense). Weed Technol. 1988, 2, 46-48. [CrossRef]

102. Elmore, C.; Roncoroni, J.; Giraud, D. Perennial weeds respond to control by soil solarization. Calif. Agric. 1993, 47, 19-22.

103. Ricci, M.S.F.; de Almeida, D.L.; Ribeiro, R.d.L.D.; de Aquino, A.M.; Pereira, J.C.; De-Polli, H.; Reis, V.M.; Eklund, C.R. Cyperus rotundus control by solarization. Biol. Agric. Hortic. 1999, 17, 151-157. [CrossRef]

104. Travlos, I.S.; Economou, G.; Kotoulas, V.E.; Kanatas, P.J.; Kontogeorgos, A.N.; Karamanos, A.I. Potential effects of diurnally alternating temperatures and solarization on purple nutsedge (Cyperus rotundus) tuber sprouting. J. Arid Environ. 2009, 73, 22-25. [CrossRef]

105. Law, D.M.; Bhavsar, V.; Snyder, J.; Mullen, M.D.; Williams, M. Evaluating Solarization and Cultivated Fallow for Johnsongrass (Sorghum halepense) Control and Nitrogen Cycling on an Organic Farm. Biol. Agric. Hortic. 2008, 26, 175-191. [CrossRef]

106. McWhorter, C.G. Factors Affecting Johnsongrass Rhizome Production and Germination. Weed Sci. 1972, 20, 41-45. [CrossRef]

107. Millhollon, R. Loose kernel smut for biocontrol of Sorghum halepense in Saccharum sp. hybrids. Weed Sci. 2000, 48, 645-652. [CrossRef]

108. Chandramohan, S.; Charudattan, R. Control of Seven Grasses with a Mixture of Three Fungal Pathogens with Restricted Host Ranges. Biol. Control 2001, 22, 246-255. [CrossRef]

109. Michael Tilley, A.; Lynn Walker, H. Evaluation of Curvularia intermedia (Cochliobolus intermedius) as a potential microbial herbicide for large crabgrass (Digitaria sanguinalis). Biol. Control 2002, 25, 12-21. [CrossRef]

110. Bridges, D.C.; Chandler, J.M. Influence of cultivar height on competitiveness of cotton (Gossypium hirsutum) with johnsongrass (Sorghum halepense). Weed Sci. 1988, 36, 616-620. [CrossRef]

(C) 2019 by the authors. Licensee MDPI, Basel, Switzerland. This article is an open access article distributed under the terms and conditions of the Creative Commons Attribution (CC BY) license (http://creativecommons.org/licenses/by/4.0/). 